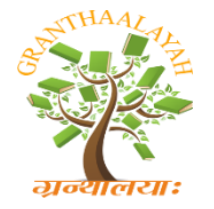
INTERNATIONAL JOURNAL OF RESEARCH - GRANTHAALAYAH A knowledge Repository

InfoBase Index IBI Factor 3.86

RASM - 17

\title{
ANALYSIS OF PROPERTIES OF CONCRETE USING HENS FEATHER DIPPED IN SALT WATER AS FIBRE REIGFORCEMENT ADMIXTURE
}

\author{
Vishal Gadgihalli ${ }^{*}$, MeenaY.R ${ }^{2}$, Anusha K R ${ }^{1}$, Aiman Hilal ${ }^{1}$, Raghavendra Prasad \\ Havanje Dinakar ${ }^{3}$ \\ ${ }^{*}$ UG Student, Department of Civil Engineering, Jain University, Bangalore, India \\ ${ }^{2}$ Assistant Professor, Department of Civil Engineering, Jain University, Bangalore, India \\ ${ }^{3}$ Research Assistant, Department of Civil Engineering, Jain University, Bangalore, India
}

DOI: https://doi.org/10.29121/granthaalayah.v5.i4RASM.2017.3367

\begin{abstract}
A material other than water, aggregates, or cement that is used as an ingredient concrete or mortor to control setting and early hardening, workability, or to provide additional cementing properties. In this paper analysis of properties of concrete using hen's feathers dipping in saltwater as admixture is studied and verified the strength of concrete to the normal Portland cement. As hens feather are most complex integumentary appendages formed in tie follicles in the epidermis, or outer skin layer that produce keratin proteins.
\end{abstract}

Keywords: Feather Fiber Reinforced Admixture; Compressive Strength; Flexural Strength; Grade of Concrete.

Cite This Article: Vishal Gadgihalli, MeenaY.R, Anusha K R, Aiman Hilal, and Raghavendra Prasad Havanje Dinakar. (2017). "ANALYSIS OF PROPERTIES OF CONCRETE USING HENS FEATHER DIPPED IN SALT WATER AS FIBRE REIGFORCEMENT ADMIXTURE." International Journal of Research - Granthaalayah, 5(4) RASM, 46-49. https://doi.org/10.29121/granthaalayah.v5.i4RASM.2017.3367.

\section{Introduction}

Admixtures are predominant materials or components used in concrete over decades attempts have been made to obtain concrete with certain desired categories such as high compressive strength, high workability, high performance and durability parameters to meet the requirement of complexity of modern structures. Feathers are epidermal growths that form distinctive outer covering or plumage, on birds. They are considered the most complex integumentary structures found in vertebrates [1] [2] and a pacifier example of a complex evolutionary novelty [3]. They are among the characteristics that distinguish the extant birds from other living groups [4]. 
Instead of dipping hen's feather in acetone solution which removes impurities, the author in present study dipped hen's feather in salt water which increased its surface tension and bond strength. Thus increases the compressive strength and flexural strength of concrete where feathers are used as concrete admixture[5].

\section{Methodology}

Feathers were collected from different sources and barbs are separated from rachis, they were dipped into salt water in the ratio of 35 grams per litre of water 2days to make barbs surface rough and it helps in good bond strength with concrete. The salt water soaked barbs are kept for drying under sunlight for a day. The barbs have been oven dried for 2 to 3 hours before mixing it into concrete. This oven drying helps in removal of water and helps in non biodegradation of barbs. Target strength of concrete was determined by the equation

Target strength $=\mathrm{f}^{\prime} \mathrm{ck}=\mathrm{fck}+1.65(\mathrm{~s})---$ [eq1] according to standard code IS10262-2009.

The amount of barbs admixture was calculated from the following equation,

Volume of feather $=($ mass of chemical admixture/specific gravity of admixture $* 1000)$ - [eq2]

The specific gravity of barbs varies from 0.23 to 1.57 the specific gravity of barb 0.83 was considered in this study. The compression and flexure strength were tested for 1, 714, 21, 28 days after casting.

\section{Results and Discussions}

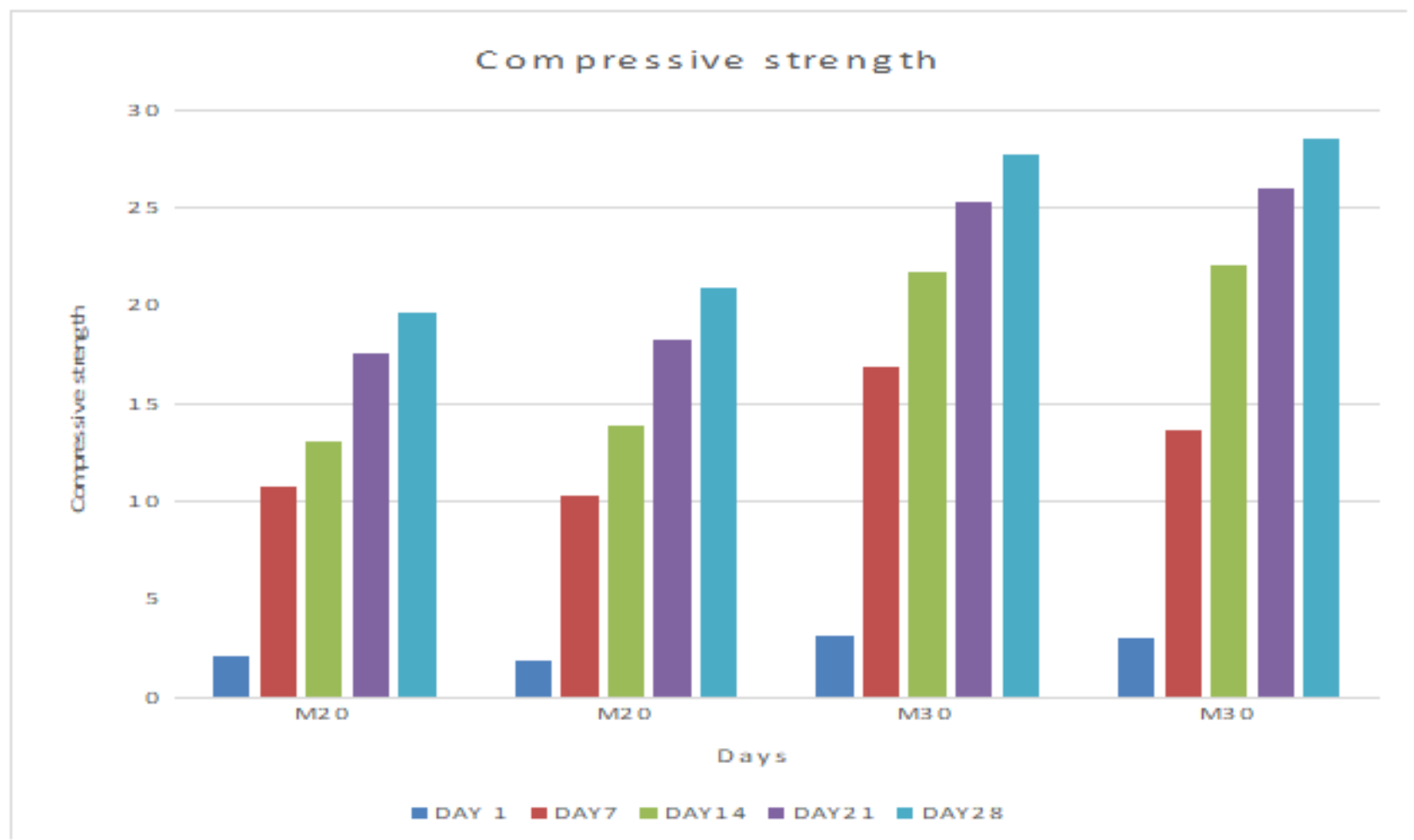




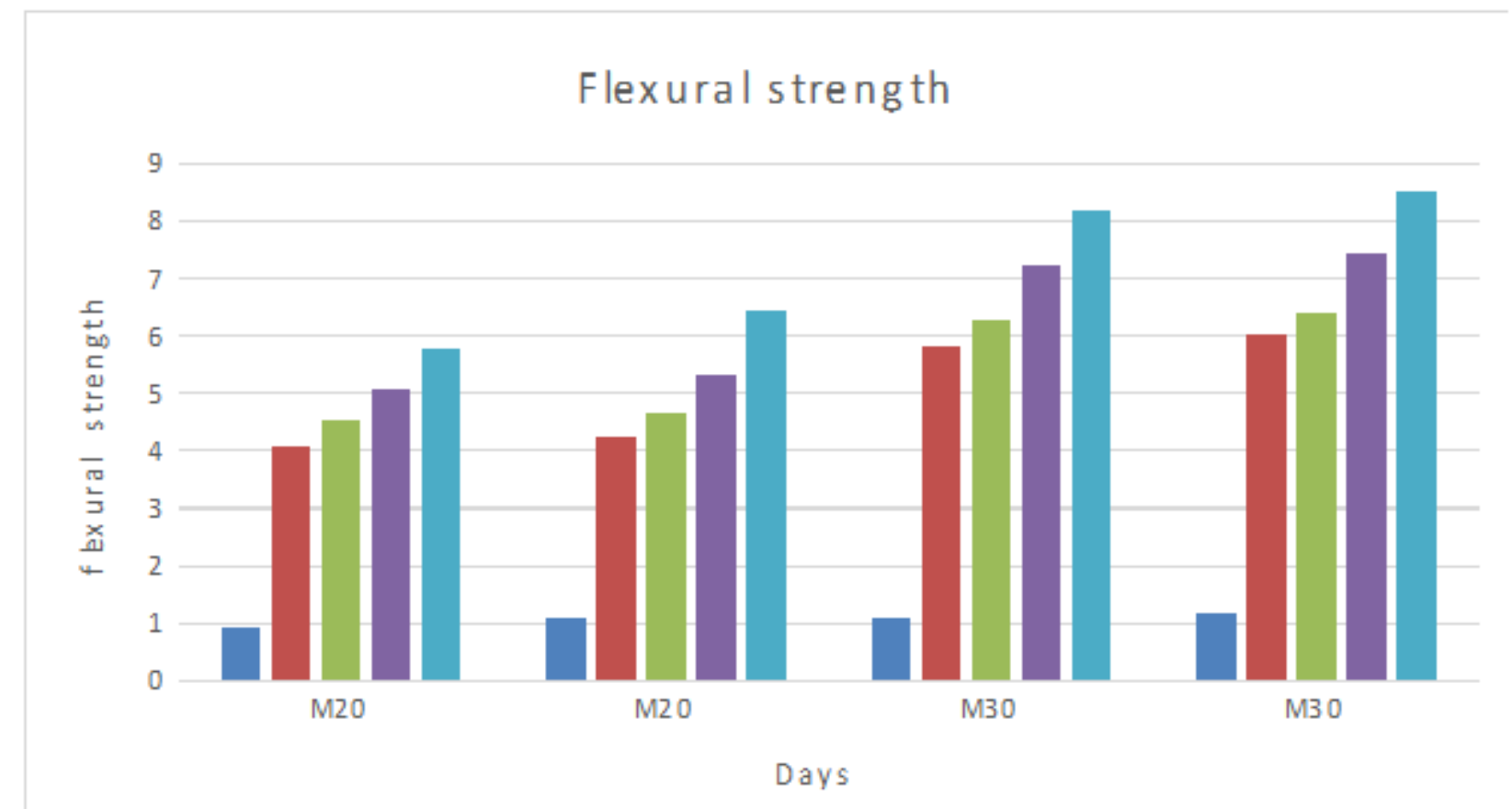

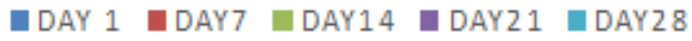

\section{Conclusions \& Recommendations}

From fig(1) it can be observed that M20 and M30 grade concrete with chicken feather as fiber reinforced admixture shows compressive strength of 20.94 and 28.54 Mpa respectively for 28 days, compared to normal concrete with 19.71 and $27.72 \mathrm{Mpa}$. This shows approximately $6 \%$ and 3\% increment in compressive strength for M20 and M30 grade respectively. From fig (2), represents flexural strength of $6.43 \mathrm{Mpa}$ and $8.53 \mathrm{Mpa}$ for M20 and M30 grade for feather as fiber reinforced concrete compared to normal concrete with 5.78 and 8.17 Mpa respectively. Thus shows approximately $10 \%$ and $4 \%$ increment in flexural strength. Hence by using chicken fiber dipped in salt water as an admixture, withstands more compressive and flexural strength than ordinary Portland cement. It is well observed as well, there is percentage reduction of compressive and flexural strength as increasing the grade of concrete.

\section{Acknowledgements}

Special thanks for Gautham Gadgihalli Hithesh Nagothu, Megha.R for helping me in completing this work successfully. And I also thank my parents, teachers, friends and all elders who supported me.

\section{References}

[1] Prum, Richard D. and AH B rush (2002). " The evolutionary origin and diversification of feathers". The quarterly review of biology. 77(3): 261-295.PMID 12365352 doi; 10.1086/341993. Retrieved 7 July 2010. 
[Gadgihalli et. al., Vol.5 (Iss.4: RASM), April, 2017]

ICV (Index Copernicus Value) 2015: 71.21

Recent Advances in Sustainable Materials
ISSN- 2350-0530(O), ISSN- 2394-3629(P)

IF: 4.321 (CosmosImpactFactor), 2.532 (I2OR)

[2] Prum, R.O. and Brush, A.H( March 2003), "which come first, the feather or the Bird?". Scientific American. 288(3):84-93.PMID 126168663. doi: 10.1088/ scientific American 0303-84. Retrieved 7 July 2010.

[3] Prum, Richard o (1999). "Development and Evolutionary origin of feathers". Journal of experimental Zoology. 285(4); 291-306. PMID 10578107. Doi; 10.1002/ (sici) 1097010x(19991215)285:4<291:: AID- jEZi> 3.0. coj; 2-9. Retrieved 7 July 2010.

[4] Li, Quango (9March 2012), "Reconstruction of Micro raptor and the Evolution of iridescent plumage", science, 335; 1215-1219, BIbcode; 20128ci-..335.1215Lm PMID 22403889, doi; $10.1126 /$ science. 1213780.

[5] Jain D. and Kothari A.: Hair fiber reinforced concrete 2012.

\footnotetext{
*Corresponding author.

E-mail address: g.vishal1912@ gmail.com
} 